\title{
The Abstract Subject of the Climate Migrant: Displaced by the Rising Tides of the Green Energy Economy
}

\author{
Dayna Scott \\ Osgoode Hall Law School of York University, dscott@osgoode.yorku.ca
}

Adrian A. Smith

asmith@osgoode.yorku.ca

Source Publication:

Journal of Human Rights and the Environment 8:1 pp. 30-50

Follow this and additional works at: https://digitalcommons.osgoode.yorku.ca/scholarly_works

Part of the Environmental Law Commons

\section{Repository Citation}

Scott, Dayna and Smith, Adrian A., "The Abstract Subject of the Climate Migrant: Displaced by the Rising Tides of the Green Energy Economy" (2017). Articles \& Book Chapters. 2690.

https://digitalcommons.osgoode.yorku.ca/scholarly_works/2690

This Article is brought to you for free and open access by the Faculty Scholarship at Osgoode Digital Commons. It has been accepted for inclusion in Articles \& Book Chapters by an authorized administrator of Osgoode Digital Commons. 


\title{
The abstract subject of the climate migrant: displaced by the rising tides of the green energy economy
}

\author{
Dayna Nadine Scott* \\ Associate Professor, Osgoode Hall Law School, York University, Toronto, Canada
}

\author{
Adrian A Smith \\ Associate Professor, Department of Law and Legal Studies, Carleton University, Ottawa, Canada
}

\begin{abstract}
A controversial proposal to build the mammoth 'Site C' dam on the Peace River in northwestern Canada offers an opportunity to explore the intersections of climate and migration issues under debate in international environmental governance circles. Site $C$ threatens to flood traditional fishing spots and traplines of Indigenous peoples in the name of the 'green energy' economy. We consider how people displaced by renewable energy projects justified as climate mitigation policies might constitute a different kind of 'climate refugee' in that they are 'displaced without moving' - the connections between the land and the people are severed to the extent that what is lost is the ability of the people to sustain themselves in a place. We demonstrate that the focus on 'security' and 'risk' in dominant approaches to the phenomenon of climate migration within the international regimes of human rights and climate governance produces contemporary commitments to 'migration management' and a prescription for 'planned relocations' that employ an abstract conception of the 'climate migrant'. The analysis reveals that the dominant international legal order on climate migration is devoid of meaningful consideration of ongoing, embodied practices of living on the land. Its abstract, universalist conceptions of land, labour and livelihoods deny the possibility of people's meaningful relations with specific places and obscure the actual 'loss and damage' that transpires when real, material and ecological relations that ground people's connections with land are severed. We conclude that, without concerted resistance and a focus on re-making the underlying structural relations, a policy emphasis on renewable energy development as 'climate mitigation' is likely to continue to produce the same inequitable patterns of benefits and burdens as climate change itself.
\end{abstract}

Keywords: green energy economy, renewable energy, climate migration, climate refugee (or environmental refugee), environmental justice (or climate justice), migration management, planned relocation, settler-colonialism

\section{INTRODUCTION}

In Canada and elsewhere in the industrialized global North, governments are introducing climate change plans that include measures to require an accounting for

* Professor Scott learned a great deal about this topic from an LLM student, Isabelle Owston, who produced an excellent major research paper entitled, 'Addressing Climate Change Migration: A Canadian Perspective', as part of her LLM at Osgoode Hall Law School in 2015-2016. Jacqueline Hebert, second-year JD student, provided expert research assistance. 
greenhouse gas (GHG) emissions meant to stimulate a transition away from fossil fuels. ${ }^{1}$ In this 'post-Paris' world, climate change is a top policy priority, and governments are striving to demonstrate that they are making progress. ${ }^{2}$ In Canada, this has meant massive new investments in so-called 'renewables', which, critically, is cast to include not just solar and wind projects, but also hydro-electric dams and nuclear refurbishment projects. ${ }^{3}$ Projects that are (and have for a long time been) highly contested by local residents and Indigenous peoples, ${ }^{4}$ are now being billed as 'green energy' initiatives and being promoted under a climate justice banner. ${ }^{5}$

In the context of this emerging green energy economy, we consider the possibility that, as Simon Dalby puts it, "those that manage to connect to this new political economy are distinguished from those dispossessed and displaced by its voracious appetite for resources and land'. ${ }^{6}$ In fact, as we demonstrate, it is possible to conceive of the people displaced and dispossessed as 'climate refugees' of a different kind. The prevailing international legal order presents an alarmist discourse of security and risk - of rising sea levels causing brown and black bodies to wash up on 'our' shores. However, as 'clean' hydroelectric projects are brought online, our accounting of those dispossessed by climate change must expand to include the marginalized peoples who are 'displaced without moving'. As Rob Nixon describes in his compelling account Slow Violence and the Environmentalism of the Poor, these people are still living on the land but they have lost the essence of the land and resources beneath them. It is 'a loss that leaves communities stranded in a place stripped of the very characteristics that made it inhabitable' for them in the past. $^{7}$

1. Government of Canada, 'Canada's Way Forward on Climate Change' (19 April 2016), online: <http://www.climatechange.gc.ca/default.asp?lang=En\&n=72F16A84-1>; European Environment Agency, 'Climate Change Policies' (3 June 2016), online: <http://www.eea. europa.eu/themes/climate/policy-context>.

2. Government of Canada, 'Canada's Priorities for COP 21' (19 April 2016), online: <http:// www.climatechange.gc.ca/default.asp?Lang=En\&xml=EF6CE373-41AA-4EFA-A97B-1EDF B25E6C83>; European Commissions, 'Toward the Paris Protocol - EU Action Areas' (22 July 2016), online: <http://ec.europa.eu/clima/policies/international/paris_protocol/index_en.htm>. 3. Government of Canada (n 1); Natural Resources Canada, 'About Renewable Energy' (29 June 2016), online: <http://www.nrcan.gc.ca/energy/renewable-electricity/7295>. 'Ontario Unveils \$12.8B Darlington Nuclear Refurbishment', CBC News (11 Jan 2016), online: <http:// www.cbc.ca/news/canada/toronto/darlington-nuclear-refurbishment-1.3395696>.

4. British Columbia's 'Site C Dam', and the Deep Geological Repository for spent nuclear fuels near the Bruce peninsula in Ontario; Amnesty International, 'Site C Dam - Human Rights at Risk' (n.d.), online: <http://www.amnesty.ca/our-work/issues/indigenous-peoples/indigenouspeoples-canada/resource-development-canada/site-c-dam $>$. B Trumpener, 'First Nations Land Occupation Aims to Stop Site C' (5 Jan 2016), online: <http://www.cbc.ca/news/canada/britishcolumbia/first-nations-land-occupation-aims-to-stop-site-c-1.3391051>. R Cain, 'Feature Part 3: Opposition to the Deep Geological Repository Plan' (16 Dec 2015), online: <http://ndlhblog. wordpress.com/2015/12/16/part-3-opposition-to-the-construction/>.

5. BC Hydro, 'Site C Clean Energy Project' (Jan 2016), online: <https://www.sitecproject. $\mathrm{com} / \mathrm{sites} / \mathrm{default} / \mathrm{files} /$ Info $\% 20$ Sheet $\% 20-\% 20$ About $\% 20$ Site $\% 20 \mathrm{C} \% 20-\% 20 \mathrm{January} \%$ 202016_1.pdf>; Sierra Club BC, 'Site C Report' (Summer 2013), online: <http://sierraclub.bc. ca/wp-content/uploads/2015/08/Site-C-Report_low-res.pdf>; Ontario Power Generation, 'What is the Deep Geologic Repository (DGR)?' (2016), online: <http://opgdgr.com/>.

6. S Dalby, 'Environmental Geopolitics in the Twenty First Century' (2014) 39(1) Alternatives: Global, Local, Political 1, 13.

7. (Harvard University, Cambridge 2011). 
We examine the 'Site C' project proposed for northwestern Canada. Site C is a massive dam to be built on the mighty Peace River flowing through the traditional territory of the Treaty 8 First Nations. Billed as a triumph in green and clean energy production, the project is certain to flood traditional traplines and fishing spots. ${ }^{8}$ In other words, the displaced Indigenous communities of the Peace Valley can be conceived of as a new brand of 'climate refugee': they are marginalized peoples displaced within the global North by a rising tide of renewable energy advocacy inattentive to environmental justice.

In this paper we seek to draw attention to the erasure of the dynamic interconnections that exist between people and the land, and are attempting to counter the lack of attention to lived experience and material connections that characterizes much of the scholarship in international environmental law. We resist the tendency to think and work within a framework that situates the environment outside of human and social interactions. This is crucial for the current project because excluding the material and ecological relations that ground people's connections with the land unnecessarily limits the kinds of political and regulatory interventions that might be made to take account of environmental justice concerns embedded in the kind of displacement that a project like Site C entails.

In section 2, we describe the Site C proposal and the government's stated justifications for the project, and place it within the broader context of the post-Paris climate regime. In section 3, we review the dominant international approaches in response to people displaced by climate change. In perceiving climate change as the growing impetus behind human migration, dominant approaches have framed the challenge in terms of risk and security. Approaches that attempt to counter these tendencies by placing the emphasis on human rights and dignity, such as through 'managed migration', often arrive at solutions that include the 'planned relocation' of impacted communities. In section 4 , we return to Site $\mathrm{C}$ to demonstrate that the dominant international legal order on climate migration employs abstract and universalist conceptions of land, labour and livelihoods which deny the possibility of people's meaningful relations with specific places. We conclude that investments in the green energy economy, especially a policy emphasis on renewable energy development as climate 'mitigation', are likely to produce the same inequitable patterns of benefits and burdens as climate change itself.'

\section{THE SITE C DAM AS CLIMATE MITIGATION AND THE DISLOCATED RESIDENTS AS 'CLIMATE MIGRANTS'}

Our people have a deep connection with this land because our ancestors told the stories and legends that are connected to that valley.

(Chief Liz Logan, Treaty 8 Tribal Association, in testimony to the Joint Review Panel) ${ }^{10}$

8. The Federal Minister of the Environment and the British Columbia Minister of the Environment, Report of the Joint Review Panel: Site C Energy Project, BC Hydro (British Columbia: the Federal Minister of the Environment, Government of Canada and the B.C. Minister of Environment, Government of British Columbia, 2014), 310-25, online: <http://www.ceaaacee.gc.ca/050/documents/p63919/99173E.pdf> [JRP Report].

9. See for example, S Alam, S Atapattu, CG Gonzalez and J Razzaque (eds), International Environmental Law and the Global South (Cambridge University Press, Cambridge 2015).

10. M Hume, 'Site C Dam Violates 100-year-old Treaty, B.C. Native Leader Says' The Globe and Mail (27 January 2014), <http://www.theglobeandmail.com/news/british-columbia/site-cdam-violates-100-year-old-treaty-bc-native-leader-says/article16537353/>. 
It is well recognized by scholars of international environmental law that climate mitigation measures create environmental justice problems and displace people. ${ }^{11}$ In most cases, these problems have arisen in the global South, as joint implementation tools established under the Kyoto Protocol, such as the Clean Development Mechanism (CDM), provided incentives for nations of the global North to 'offset' their greenhouse gas (GHG) emissions by investing in carbon sequestration and renewable energy projects in developing countries. ${ }^{12}$ Also long recognized is that dams are accompanied by devastating human rights violations, including in some cases forced displacement, loss of land, and the destruction of subsistence ways. ${ }^{13}$ Dams that are brought forward as CDM projects, on account of the fact that they constitute climate change mitigation efforts, typically are not subject to the same degree of environmental or human rights scrutiny as they otherwise would be. ${ }^{14}$

The Site $\mathrm{C}$ project will be the third in a series of dams and generation stations on the Peace River, which gathers its waters in the Rocky Mountain range of northern British Columbia and flows towards the northeast, draining into the Slave River at Peace Point in northern Alberta. Several First Nations and Métis communities rely on the valley for hunting and fishing, and other traditional practices such as gathering berries and sacred medicines, and holding ceremonies. ${ }^{15}$ The valley holds the places where their ancestors are buried. ${ }^{16}$

In the 1950s, Site $C$ received its name from surveyors putting down five possible sites for dams on a map of the Peace River: it is an 'abstract signifier', a reflection of the modernist view of progress that prevailed at the time. ${ }^{17}$ Two decades later when the site came under serious consideration, it was pushed back by a wave of opposition. ${ }^{18}$ But in the contemporary moment, instead of 'modernism', Site C signifies clean energy: the dam 'sits at the centre of the BC government's Energy Plan,

11. N Roht-Arriaza, 'Human Rights in the Climate Change Regime' (2010) 1(2) JHRE 211 at 218 [Roht-Arriaza]. Jane McAdam and Elizabeth Ferris, 'Planned Relocations in the Context of Climate Change: Unpacking the Legal and Conceptual Issues' (2015) 4(1) J Int'l \& Comp L 137 at 142 [McAdam \& Ferris]: palm oil cultivation, which is heralded as a way of decreasing carbon emissions through biofuels.

12. E Boyd, 'Governing the Clean Development Mechanism: Global Rhetoric Versus Local Realities in Carbon Sequestration Projects' (2009) 41(10) Environment and Planning A 2380.

13. Roht-Arriaza (n 11), 215.

14. B Haya and P Parekh, 'Hydropower in the CDM: Examining Additionality and Criteria for Sustainability' (2011) Energy and Resources Group, University of California, Berkeley 4, online: <https://www.internationalrivers.org/sites/default/files/attached-files/haya_parekh2011-hydropower_in_the_cdm_0.pdf>; World Commission on Dams (WCD) standards are typically not applied to CDM projects.

15. Site C First Nation Engagement Team, 'Site C Clean Energy Project, Volume 3 Appendix F: Current Use of Lands and Resources for Traditional Purposes Summary', online: <https://www. ceaa-acee.gc.ca/050/documents_staticpost/63919/85328/Vol3_Appendix_F.pdf>. M Hume, 'First Nations in Northern B.C. Worry Site C Dam will Obliterate their Heritage', The Globe and Mail (28 August 2015), online: <http://www.theglobeandmail.com/news/british-columbia/ site-c/article26154330/>.

16. Ibid.

17. M Evenden, 'Site C Forum: Considering the Prospect of Another Dam on the Peace River' (2009) 161 BC Studies 93, 93 [Evenden].

18. Treaty 8 Tribal Association, 'About Site C' (2015), online: <http://treaty8.bc.ca/aboutsite-c/>. 
which aims to reduce dependence on imported electricity and to find new sources of emissions-free generation to meet the rising electricity demands of the province' ${ }^{19}$

Site C also falls into the territory covered by Treaty No. 8. Entered into in 1899 , Treaty No. 8 is one of the so-called numbered treaties concluded between the federal Crown and various First Nations in order to facilitate the 'expansion of colonial settlement into the western half of what is now Canada'. ${ }^{20}$ The Treaty provides for the continuation of the First Nations' 'usual vocations of hunting, trapping, and fishing' throughout the Treaty territory. Further, oral promises made by the Crown at the time of signing make clear that for the First Nations the 'same means of earning a livelihood would continue after the Treaty as existed before it'; 'they would be as free to hunt and fish after the Treaty as they would be if they never entered into it'; and, the Treaty would not lead to 'forced interference with their mode of life'. Furthermore, jurisprudence has established that the Treaty should be interpreted as providing assurances of continuity in traditional patterns of harvesting and other evolving forms of economic activity. ${ }^{21}$

The proposed $\$ 8$ billion dam project will flood $80 \mathrm{~km}$ of the river valley, inundating grave sites, making traplines and fishing spots inaccessible and displacing ceremonies. A Joint Review Panel (the 'Panel' or 'JRP') established by the Federal Minister of the Environment and the British Columbia Minister of Environment in August 2013 to conduct an environmental assessment of the project found that it would impose a long list of social and environmental costs. ${ }^{22}$ The Panel describes some of the worst impacts as follows:

- Significant unmitigated losses to wildlife and rare plants, including losses to species under the Species at Risk Act and to game and plant resources preferred by Aboriginal peoples;

- Significant unmitigated losses to fish and fish habitat, including three distinct sub-groups of fish preferred by Aboriginal peoples, one of which is federally listed as a species of special concern;

- Losses of certain valuable archaeological, historical and paleontological resources;

- Social costs to farmers, ranchers, hunters, and other users of the Peace River valley, and;

- Forced changes to the current use of lands and waters by signatories to Treaty 8, other First Nations and Métis, whose rights are protected under article 35 of the Constitution Act, $1982 .^{23}$

Despite the 'unprecedented number' of significant adverse impacts, ${ }^{24}$ the Panel justified the proposed plans by noting that there is a 'public interest in long-term, reliable electricity to meet growing demand' and found that the Project could meet these demands with 'lower GHG impact than other resource options'. ${ }^{25}$ Further, the Panel noted 'employment, economic development, ratepayer, taxpayer, and community benefits'

19. Evenden (n 17), 94.

20. Site C: Statement by Concerned Scholars, 'Briefing Note \#1: First Nations and Site C' (24 May 2016), 1, online: <https://sitecstatement.files.wordpress.com/2016/01/briefing-note-1-firstnations-and-site-c1.pdf> [Briefing Note].

21. See, for example, $R v$ Sparrow [1990] 1 SCR 1075, 70 DLR (4th) 385; Mikisew Cree First Nation v Canada (Minister of Canadian Heritage) 2005 SCC 69, [2005] 3 SCR 388; and West Moberly First Nations $v$ British Columbia (Ministry of Energy, Mines and Petroleum Resources) 2011 BCCA 247 [2011], BCJ No 942.

22. JRP Report (n 8).

23. Ibid 307.

24. Briefing Note (n 20), 13.

25. JRP Report (n 8), 275. 
and stated that the 'limited footprint of the Project, given its generation capability, using water already stored in the upstream reservoirs' made it particularly attractive. ${ }^{26}$ The Panel also found that there had been an 'honourable process of engagement with Aboriginal groups' and that there would be 'potential for accommodation of their interests'. ${ }^{27}$ BC Hydro, the project proponent, did hold consultations with some of the local Indigenous groups and organizations who stand to lose ancestral lands, fishing spots, hunting territory and historic traplines, and the Federal Court, in response to a court challenge later filed by those groups, described the consultation as 'extensive and conducted in good faith'. ${ }^{28}$

However, this was not an open-ended consultative process that respected Indigenous peoples' rights to grant or withhold their 'free, prior and informed consent' (FPIC) before decisions about resource developments are allowed to proceed on their territories. The right to FPIC is a central pillar of the UN Declaration on the Rights of Indigenous Peoples,${ }^{29}$ to which Canada is now a 'full adherent' according to its new federal government. ${ }^{30}$ In fact, British Columbia's Clean Energy Act 2010, played a pivotal role in the recent revival of the Site $C$ proposal. Specifically, the Act exempts the project from certain procedural requirements that would have ensured a more thorough consultation with affected First Nations. ${ }^{31}$ Many of these First Nations stated that for their members fishing was a traditional practice that depended on specific places, species and means, and these fishing spots were crucial to the cultural and subsistence activities of their members. ${ }^{32}$ Many members indicated that knowledge about fishing sites and fishing stories had been transferred through oral histories for generations. ${ }^{33}$

The Treaty 8 Tribal Association (T8TA) said preferred fish species are harvested in specific culturally known locations that are unique to the Peace River valley and described the Peace River valley as its 'grocery store' ${ }^{34}$ It said the valley was a preferred area for fishing, hunting, and food and medicinal plant gathering for several reasons, including accessibility, deep cultural attachment, proximity to areas where

26. Ibid.

27. Ibid 276. In providing its approval for the dam, the Joint Review Panel concedes that the 'timing of the need [for more power] is necessarily uncertain' and that 'the Proponent has not fully demonstrated the need for the Project on the timetable [provided]'. In an apparent attempt to neutralize this shortcoming, it provides some philosophical insight into how one places value on the present versus the future. It says that '[i]f today's society values current over future consumption, such a project is daunting' and adds that, as time passes, inflation will erode the project's initial high cost, such that 'Site C could appear as a wonderful gift from the ancestors of that future society' (ibid 307).

28. Prophet River First Nation v Canada (AG) 2015 FC 1030, para 62.

29. United Nations Declaration on the Rights of Indigenous Peoples, United Nations General Assembly, 61st session, UN Document A/RES/61/295 (2 October 2007) [Declaration].

30. M-D Smith, 'Report Warns a Literal Reading of UN Indigenous Rights Declaration Could Lead to "Discord"' National Post (19 May 2016), online: <http://news.nationalpost.com/news/ canada/canadian-politics/report-warns-a-literal-reading-of-un-indigenous-rights-declarationcould-lead-to-discord>.

31. Briefing Note (n 20), 23. See also, Clean Energy Act, S BC 2010, c 22, s 7(1)(d).

32. Three Treaty 8 First Nations, Blueberry River, Saulteau and McLeod Lake, agreed to support the project and negotiated compensation through impact benefit agreements with the project proponent.

33. Ibid.

34. JRP Report (n 8), 101. 
members live, abundant wildlife and natural resources, and unique cultural and ecological value. Chief Darlene Hunter from Halfway River First Nation said that the Peace River was in many ways their 'last refuge', given the high level of development in the Region.

Members of the McLeod Indian Band said they rely on the Peace River for subsistence and that other viable hunting, fishing and harvesting sites are limited within their territory. They stated that their territory along the Peace River is highly valued because of the great animal and plant diversity and the abundance of natural resources. ${ }^{35}$ Finally, there were claims that the dam would decimate moose populations and poison fish with toxic methyl mercury, ${ }^{36}$ despite the fact that the river has been called the Indigenous people's 'lifeblood'. ${ }^{37}$

\section{DOMINANT APPROACHES TO CLIMATE MIGRATION IN THE INTERNATIONAL LEGAL ORDER}

The international legal order that we consider here includes the climate governance regime, focused on the United Nations Framework Convention on Climate Change (UNFCCC) and the recent Paris Accord. In a more tangential way, it also includes the broader refugee protection and human rights regimes. The UNFCCC was adopted in 1992 and now has 197 state parties. ${ }^{38}$ The UNFCCC's ultimate objective is to achieve the 'stabilization of greenhouse gas concentrations in the atmosphere at a level that would prevent dangerous anthropogenic interference with the climate system' ${ }^{39}$ The international community of states focused on the aim of climate mitigation: Article 3 of the Convention deals with the need to protect the environment for the 'benefit of present and future generations of humankind', and to 'prevent or minimize the causes of climate change' ${ }^{40}$ There were no references to the idea that climate change might induce human migration in the original Convention; even 'adaptation' received little

35. Ibid. Further, Band Councillor Clarence Willson stated in Justine Hunter, 'BC Hydro Faces Widespread Community Opposition Over Dam', The Globe and Mail (7 December 2013), online: $<$ http://www.theglobeandmail.com/news/british-columbia/bc-hydro-faces-widespread-communityopposition-over-dam/article15816152/>: 'The valley is abundant in life, moose and elk and deer and all kinds of beaver, all the life in that valley, destroyed permanently so that big companies can have cheap electricity. That doesn't make sense to us ... We don't believe this is a project that can be reconciled with our treaty rights. It's too much impact on an already fragile land base.' 36. JRP Report (n 8), 101. Chief Roland Willson of West Moberly First Nation believes mercury contamination problems, such as occurred at the W.A.C. Bennett dam, will reoccur if the Site C Dam is built: 'It is exactly the same environment and what would happen is that it would pass through one dam to the next dam', see: Roy L Hales, 'Mercury Contamination Stiffens Opposition to Site C Dam', The ECOreport (13 May 2015), online: <https://theecoreport. com/mercury-contamination-stiffens-opposition-to-site-c-dam/> [Hales].

37. Hales (n 36), Chief Roland Willson stated: 'We are all opposed to it. There are (only) 4 First Nations that are in court, because it costs lots of money. We are taking on BC and BC Hydro, the two wealthiest opponents in the province. They have lawyers crawling out of the woodwork and we are a small group of First Nations trying to protect our treaty rights'.

38. United Nations Framework Convention on Climate Change (UNFCCC), 'Status of Ratification of the Convention', online: <http://unfccc.int/essential_background/convention/ status_of_ratification/items/2631.php>.

39. United Nations Framework Convention on Climate Change, 9 May 1992, 1771 UNTS 107 (entered into force 21 March 1994), Art 2 [UNFCCC].

40. Ibid. 
attention outside of vague references to the aims of mitigating climate change's 'adverse effects' and of promoting 'sustainable development' ${ }^{41}$ The UNFCCC was not 'designed to provide human rights protection and humanitarian aid to individuals'; it was designed to tackle a global atmospheric phenomenon that was only starting to be understood. ${ }^{42}$

As a 'framework' Convention, the UNFCCC allows state parties to negotiate further protocols to achieve their aims as circumstances develop and change. This proved to be very useful as parties gradually came to terms with the unavoidable fact that their meagre mitigation efforts were failing and 'adaptation' efforts would be critical to avoid widespread human suffering related to climate change. Accordingly, the language of 'human mobility' in the context of climate change entered the lexicon in 2010 at the Conference of the Parties (COP) in Cancun where the parties undertook 'measures to enhance understanding, coordination and cooperation with regard to climate change induced displacement, migration and planned relocation, where appropriate, at the national, regional and international levels' ${ }^{43}$

In 2012, the COP shifted questions of displacement to a 'loss and damage' approach, agreeing to advance understanding of how the 'impacts of climate change are affecting patterns of migration, displacement and human mobility'. ${ }^{44}$ A year later at COP 19, the parties established the Warsaw Mechanism for Loss and Damage (Warsaw Mechanism) with the directive to 'address' loss and damage associated with climate change. Losses could stem from 'extreme events and slow onset events', especially in vulnerable low-lying and coastal communities in developing countries. ${ }^{45}$

The Paris Accord, established during COP $21^{46}$ in 2015, is said to outline a future global agenda for climate action according to the principles of equity, solidarity and sustainability in accordance with the Sustainable Development Goals adopted by the

41. R Verheyen and P Roderick, 'Beyond Adaptation: The Legal Duty to Pay Compensation for Climate Change Damage' (WWF-UK Report) (November 2008). It should be noted however, that the Alliance of Small Island States called in 1991 for the establishment of an 'international insurance pool' to compensate victims of sea level rise.

42. Ibid.

43. Conference of the Parties, Decision 1/CP.16, The Cancun Agreements: Outcome of the work of the Ad Hoc Working Group on Long-term Cooperative Action under the Convention art 14(f) (our emphasis).

44. Conference of the Parties, Decision 3/CP.18, Approaches to address loss and damage associated with climate change impacts in developing countries that are particularly vulnerable to the adverse effects of climate change to enhance adaptive capacity, art 7(a)(vi). Under the UNFCCC, 'loss and damage' has been defined as 'the actual and/or potential manifestation of impacts associated with climate change in developing countries that negatively affect human and natural systems', see S Huq and R-M De Souza, 'Climate Compensation: How Loss and Damage Fared in the Paris Agreement' Wilson Center on COP-21, New Security Beat (12 January 2016), online: $<$ https://www.newsecuritybeat.org/2016/01/loss-damage-fared-paris-agreement/> [Huq and De Souza] citing UNFCCC, 'Approaches to address loss and damage associated with climate change impacts in developing countries that are particularly vulnerable to the adverse effects of climate change to enhance adaptive capacity', Subsidiary Body for Implementation, 37th session, Doha (15 November 2012).

45. Jessica Wentz and Michael Burger, 'Designing a Climate Change Displacement Coordination Facility: Key Issues for COP 21' (2015) Sabin Center for Climate Change Law, Columbia Law School at 3: 'In other words, the mechanism was introduced to provide technical and financial support to poorer countries that are disproportionally impacted by climate change'. 46. Conference of the Parties, Draft decision -/CP.21, 'Adoption of the Paris Agreement' [COP 21 Decision]. 
UN General Assembly earlier that year. ${ }^{47}$ The Accord relies primarily on a 'pledge and review' mechanism through which state parties make a voluntary 'pledge' in relation to their 'greenhouse gas emissions limiting ambition', which is then subject to a legally binding review process to monitor the extent of their fulfilment of the pledge. It was anticipated that the agreement would call for a 'climate change displacement coordination facility', but this was ultimately not included in the final text of the agreement.

Some advocates were pleased to see language in the preamble of the Paris Agreement acknowledging the importance of respecting, promoting and considering obligations towards migrants when addressing climate change. ${ }^{48}$ Others were disappointed that it stopped short of establishing a legal status for climate migrants and designating an agency that would be responsible for their protection. ${ }^{49}$ COP 21 furthers the discussion of climate migration under the framework of 'loss and damage'. It calls for the establishment of a task force to 'develop recommendations for an integrated approach to avert, minimize and address displacement related to the adverse impacts of climate change' ${ }^{50}$ The Warsaw Mechanism for Loss and Damage is also embedded within the Paris Agreement itself at article 8.

Commentators have expressed concern that 'the Paris outcome clearly showed who has the power to define the outcome of these sorts of agreements - it's not the most vulnerable developing countries, no matter what moral weight they carry ...' ${ }^{51}$ Yet, in 'an era of fractured multilateralism', as some have noted, it achieved more than most considered politically possible. At the same time, with pledges that cumulatively can only hope to limit warming to about 3 degrees, the Paris Agreement is far short of what is 'necessary to stop dangerous climate change', never mind build in any concrete 'climate recovery steps'. 52

\section{1 'Loss and damage'}

Much of the debate in the international legal arena is about who should pay the costs of climate change. As of now, with the world already experiencing about 1 degree of

47. The Sustainable Development Gaols constitute the agenda of the United Nations Development Program for the next 15 years. They came into effect in January 2016: UNDP, online $<$ http://www.undp.org/content/undp/en/home/sustainable-development-goals/>.

48. The exact words of the Preamble are 'Acknowledging that climate change is a common concern of humankind, Parties should, when taking action to address climate change, respect, promote and consider their respective obligations on human rights, the right to health, the rights of indigenous peoples, local communities, migrants, children, persons with disabilities and people in vulnerable situations and the right to development, as well as gender equality, empowerment of women and intergenerational equity'.

49. K Lambert, 'The Paris Agreement: Spotlight on Climate Migrants', Yale School of Forestry and Environmental Studies (29 December 2015), online: <https://environment.yale. edu/blog/2015/12/the-paris-agreement-spotlight-on-climate-migrants/> [Lambert, The Paris Agreement: Spotlight on Climate Migrants].

50. COP 21 Decision, Article 50 (our emphasis).

51. J Chemnick, 'Fiji Cyclone Disaster Is a Sign of Future Challenges' Scientific American (24 February 2016) online: <http://www.scientificamerican.com/article/fiji-cyclone-disasteris-a-sign-of-future-challenges $/>$.

52. K Boom, J-A Richards and S Leonard, 'Climate Justice: The International Momentum Towards Climate Litigation' Climate Justice Program, 2016, at 2 (removed from Climate Justice webpage, on file with author). 
warming, 'the poorest and most vulnerable communities are paying for loss and damage - with their lives, their homes, or their ability to grow food' ${ }^{53}$ Major industrialized countries of the global North have opposed the recognition of 'loss and damage', saying that paying compensation could be akin to an admission of liability - sometimes rejected in negotiations as a demand that they issue a 'blank check'. ${ }^{4}$

The IPCC predicted in 1990 that the 'gravest threat' associated with climate change might be expected impacts on human migration. ${ }^{55} \mathrm{By}$ the time of the 5 th Assessment Report, the IPCC states that the movement of people around the world is 'intrinsically linked to climate change' and predicts that this trend will only accelerate. In fact, people across the global South, as well as those living in the most marginalized conditions in the global North, are already experiencing extreme weather events such as typhoons, floods and droughts 'like never before'. 56

The language of 'climate justice' finally penetrated the international legal order with the Paris Accord, in a 'miserly acknowledgement' in the Preamble. ${ }^{57}$ Climate injustice is typically described as follows:

Wealthy countries and large multinational fossil fuel companies, have gained their wealth and security at the expense of billions of poor people living in highly vulnerable circumstances around the world, and have shown no intention to compensate for the harm caused and little enthusiasm for mitigating the harm by reducing emissions. Climate change creates a huge intergenerational justice issue as the harms resulting from climate change will disproportionately burden youth and future generations relative to present generations ... [at the core is the] inherent unfairness that the people who have done the least to cause climate change are the ones who will face the worst impacts. ${ }^{58}$

While migration has occurred throughout history in response to environmental hazards and changing weather patterns,${ }^{59}$ it is now widely acknowledged that climate change is altering the nature of human migration. This is attributed to the immense numbers of people that are expected to move and the urgency with which population movements will occur. ${ }^{60}$

53. Ibid 2. See also: K Warner, K van der Geest, S Kreft, S Huq, S Harmeling, K Kusters and A De Sherbinin, Evidence from the Frontlines of Climate Change: Loss and Damage to Communities Despite Coping and Adaptation, UNU-EHS Report (UNU-EHS 2012).

54. Boom et al. (n 52), 10.

55. Policymakers Summary to the IPCC first assessment report, 1990, 103.

56. Boom et al. (n 52), 6.

57. Ibid 7 .

58. Ibid.

59. J McAdam, Climate Change, Forced Migration, and International Law (Oxford University Press, New York 2012).

60. B Mayer 'The International Legal Challenges of Climate-Induced Migration: Proposal for an International Legal Framework' (2011) 22(3) Colo J Intl Envtl L \& Pol'y 357, 362. Studies have predicted that between 200 and 250 million people will be displaced over the coming decades. See F Biermann and I Boas, 'Preparing for a Warmer World: Towards a Global Governance System to Protect Climate Refugees' (2010) 10(1) Global Environmental Politics 60, 68. These predictions are contested, of course, as methodologies vary, definitions are in flux and many predictions fail to include the large proportion of people who are expected to be internally displaced within their country of origin. See eg, J Barnett and M Webber, 'Accommodating Migration to Promote Adaptation to Climate Change', Background Paper to the 2010 World Development Report, Policy Research Working Paper 5270 (The World Bank, April 2010), 45. 
As can be seen, the dominant approaches to climate change in international law focus on climate mitigation, and to the extent that they are beginning to consider climate-induced migration, they tend to be focused on people displaced by the effects of climate change. In that regard, the debate is characterized by the enduring tension between the global North and the global South over "common but differentiated responsibilities'. ${ }^{61}$ The critical point to take forward into the remainder of this article is that climate injustice (in relation to both migration caused by climate change and displacement caused by climate mitigation policies) hinges on the fact that those displaced and dispossessed are those least responsible for climate change.

\subsection{Characterizing the dominant approaches to climate migration}

Significant debate surrounds how issues of migration, development, security and environment intersect. While there has been decades-long concern for how environmental change or stress affects migration, the most recent iteration perceives climate change as a more acute form of environmental stress that induces migration. These perspectives perceive displacement through migration as a problematic consequence of climate change. There is considerable concern and even fear that climate-induced mass migration will lead to large-scale population movements and displacement. In fact, the literature is awash with alarmist predictions that the number of "climate refugees' will soon exceed the number of 'Convention refugees' and warnings that dramatic, unpredicted large-scale displacement may overwhelm the international community, presenting not only humanitarian crises but also national security concerns. ${ }^{62}$ The Guardian and others have gone as far as to warn of 'climate wars', ${ }^{63}$ and political and scholarly commentators have taken to referring to climate or environmental 'refugees'.

The first substantive use of the term 'environmental refugee' in the UN context occurred in a United Nations Environmental Programme (UNEP) report in 1985.64 This initial definition construed 'environmental refugees' as 'those people who

61. See eg, S Atapattu and CG Gonzalez, 'The North-South Divide in International Environmental Law: Framing the Issues' in S Alam, S Atapattu, CG Gonzalez and J Razzaque (eds), International Environmental Law and the Global South (Cambridge University Press, Cambridge 2015) $1-22$.

62. These claims mirror those advanced on 'environmental scarcity', see eg Thomas HomerDixon, 'On the Threshold: Environmental Changes as Causes of Acute Conflict' (1991) 16 International Security 76; T Homer-Dixon and V Percival, Environmental Security and Violent Conflict: Briefing Book (University of Toronto and American Association for the Advancement of Science, Toronto 1996).

63. R McKie, 'Climate Wars Threaten Billions' The Guardian (4 November 2007), online: $<$ https://www.theguardian.com/environment/2007/nov/04/climatechange.scienceofclimate change>; J Vidal, 'Have the Climate Wars Begun?' The Guardian (21 September 2010), online: $<$ https://www.theguardian.com/global-development/poverty-matters/2010/sep/21/climate-warsmachu-picchu-irrigation>; P Hockenos, 'The Climate Wars are Coming - and More Refugees with Them' Al Jazeera America (15 September 2015), online: <http://america.aljazeera.com/ opinions/2015/9/the-climate-wars-are-coming-and-more-refugees-with-them.html>.

64. E El-Hinnawi, 'Environmental Refugees', United Nations Environmental Programme (Report) (1985). While El-Hinnawi is credited with popularizing the term, Lester Brown, founder of the World Watch Institute, first used it in the 1970s; see PL Saunders, 'Environmental Refugees: The Origins of a Construct' in P Stott and S Sullivan (eds), Political Ecology: Science, Myth and Power (Arnold, London 2000). 
have been forced to leave their traditional habitat, temporarily or permanently, because of a marked environmental disruption (natural and/or triggered by people) that jeopardized their existence and/or seriously affected the quality of their life'. ${ }^{65}$ The formative work of conservation biologist Norman Myers re-characterized environmental refugees as 'fast-growing numbers of people who can no longer gain a secure livelihood in their homelands because of drought, soil erosion, desertification, deforestation and other environmental problems'. ${ }^{66}$ A robust academic debate ensued which, while too voluminous to detail here, has been found to have core 'maximalist' and 'minimalist' currents. ${ }^{67}$ Some have sought to question the broad or 'maximalist' framings of El-Hinnawi and Myers, ${ }^{68}$ including on the grounds that they (and their adherents) grossly overstate the empirical record and adopt problematic 'neo-Malthusian' concerns about over-population. ${ }^{69}$ As such, the climate refugee is cast as a threat to wealthy national states of the global North, including to the so-called "critical infrastructure' of those states. This fear mongering has led to an intensification of restrictive migration and border controls, and framed calls for national state intervention through militarism. ${ }^{70}$ A core assumption is that contemporary migration, including in climateinduced forms, represents a challenge to state sovereignty and autonomy and national territorial borders ${ }^{71}$ - a point to which we return below.

In contrast, 'minimalist' accounts sought to reject 'a deterministic view on migration' as a direct result of environmental change and 'the invocation of a security lexicon', ${ }^{72}$ arguing instead that environmental change constitutes 'a contextual variable that can contribute to migration', yet not ultimately drive the decision-making of migrants. ${ }^{73}$

65. E El-Hinnawi, ibid 4.

66. N Myers, 'Environmental Refugees' (1997) 19(2) Population and Environment 167, 167, cited in S Castles, 'Environmental Change and Forced Migration: Making Sense of the Debate' (Working Paper 70) (2002). For a fuller discussion see N Myers and J Kent, Environmental Exodus: An Emergent Crisis in the Global Arena (Climate Institute Report) (1995).

67. A Suhrke, 'Environmental Degradation and Population Flows' (1994) 47(2) Journal of International Affairs 473. For a revised perspective see J Morrissey, 'Rethinking the "Debate on Environmental Refugees": From "Maximilists and Minimalists" to "Proponents and Critics"” (2012) 19 Journal of Political Ecology 36.

68. But see R Black, 'Environmental Refugees: Myth or Reality?' (UN High Commissioner for Refugees Working Paper No. 34) (2001); R Black, Refugees, Environment and Development (Longman, Essex 1998).

69. R Black, Refugees, Environment and Development, ibid; Black, 'Environmental Refugees: Myth or Reality?' ibid.

70. G Bettini, 'Climate Barbarians at the Gate? A Critique of Apocalyptic Narratives on "Climate Refugees"' (2013) 45 Geoforum 63; B Hartmann, 'Rethinking Climate Refugees and Climate Conflict: Rhetoric, Reality and the Politics of Policy Discourse' (2010) 22(2) Journal of International Development 233; PJ Smith, 'Climate Change, Mass Migration and the Military Response' (2007) 51(4) Orbis 617. On the origins of the environmental refugee framing see Saunders (n 64). For competing framings see DC Bates, 'Environmental Refugees? Classifying Human Migrations Caused by Environmental Change' (2002) 23(5) Population and Environment 465. For an earlier take see Myers and Kent (n 66).

71. McAdam and Ferris (n 11), 142: the "interaction between the effects of "natural" phenomena' like floods 'and socio-economic factors' namely 'impoverishment that will make relocation necessary. It is impossible to attribute movement to climate change or disasters alone. Rather, it is a multi-causal phenomenon'.

72. G Bettini, 'Climate Migration as an Adaption Strategy: De-Securitizing Climate-Induced Migration or Making the Unruly Governable?' (2014) 2(2) Critical Studies on Security 180.

73. Suhrke (n 67). 
Yet in their own way, 'minimalist' accounts participate in the promotion of fear of the environmental refugee. Not only did these framings "coincid[e] with moments in which migrants and asylum seekers were increasingly being perceived as a problem', they are also 'reliant on the portrayal of refugees/migrants as problematic in order to rationalize policy aimed at environmental protection' ${ }^{74}$ In other words, the spectre of brown and black bodies at the borders was used to convince state decision-makers to take climate mitigation aims seriously.

However, climate-induced migration is not easily addressed within the international refugee law protection regime. Whether defined as 'environmental refugees', 'environmentally-displaced persons', 'climate migrants', 'climate refugees', or now commonly 'climate displaced persons (CDPs)', ${ }^{75}$ these migrants do not fit within the accepted meaning of 'refugee', as defined in the Refugee Convention of 1951, as their movement is not easily characterized as resulting from state 'persecution'. ${ }^{76}$ Scholars disagree about whether the term should cover those whose movement is permanent or only temporary; voluntary or forced; related to environmental change that is slow-onset or only sudden. There is also a dearth of protections for the climate refugee or migrant in the international human rights regime. ${ }^{77}$ For some, the international community owes a moral obligation to those displaced and the principle of inherent dignity offers a viable response, as we will come to see. ${ }^{78}$

All this said, the contestation over framings has limited utility in that it addresses "the legitimacy of the term "environmental refugee", rather than [extending] a debate about the appropriate conception of the relationship between environmental change/ stress and human mobility - a relationship about which there appears to be general agreement' ${ }^{79}$ As Morrissey maintains, proponents of the term seek to motivate a search for solutions to 'looming environmental crises and the subsequent human vulnerability such crises might entail', whereas opponents question the appropriateness of the term, identifying as the critical issue how the term fuels an anti-migrant stigma or animus. ${ }^{80}$

Interrogating wealthy states' narrow emphasis on national security and the control of territorial borders, critical scholarly approaches have also sought to revisit risk and security framings. The contestation of prevailing climate change politics turns on an application of securitization theory, a set of critical approaches formulated within

74. Morrissey (n 67).

75. R Lyster, 'Protecting the Human Rights of Climate Displaced Persons: The Promise and Limits of the United Nations Framework Convention on Climate Change' in A Grear and L Kotzé (eds), Research Handbook on Human Rights and the Environment (Edward Elgar, Cheltenham, UK 2015) 423-48; B Docherty and T Giannini, 'Confronting a Rising Tide: A Proposal for a Convention on Climate Change Refugees' (2009) 33(2) Harvard Environmental Law Review 349, 352; Biermann and Boas (n 60); K Moberg speaks of 'Environmentally Displaced Persons' in KK Moberg, 'Extending Refugee Definitions to Cover Environmentally Displaced Persons Displaces Necessary Protection' (2008-2009) 94 Iowa L. Rev. 1107, 1107. 76. S Atapattu, Human Rights Approaches to Climate Change: Challenges and Opportunities (Routledge, New York 2015).

77. See Atapattu, ibid; T Faist and J Schade (eds), Disentangling Migration and Climate Change: Methodologies, Political Discourses and Human Rights (Springer, Dordrecht and New York 2013).

78. Atapattu (n 76), 173.

79. Morrissey (n 67), 43.

80. Ibid 43 . 
international relations theory. ${ }^{81}$ The critical intervention problematizes the 'securitization of climate migration' as the subsumption of the climate and migration political nexus into the realm of security perceived to be devoid of politics. ${ }^{82} \mathrm{~A}$ more recent shift in focus appears evident in that the presumption that environmental migration is 'forced' has 'given way to the idea that migration can also represent an adaptation strategy' ${ }^{83}$ However, it is not that ' $[\mathrm{t}]$ he security lexicon has been replaced ...', but that calls for 'human security, resilience and adaptation' 84 exist simultaneously with national security framings. The co-existence of securitization and human security accounts in fact characterizes what is now known as the 'migration management' approach.

\subsection{The prevailing solution offered by the international legal order: climate migration management}

Migration management represents a contemporary global policy aimed at transforming disorderly migratory flows into orderly ones. ${ }^{85}$ It appears to advance a rationale for global coordination on migration, yet its organization occurs in and through the national state. Organized around 'nationalized governance of migration', migration management affirms a central coordinating role for national states in the regulation of human mobility, notwithstanding a range of claims to the contrary. Within the contemporary national state system, states regulate the trans-border movement of people relying on the principles of sovereignty and territoriality. Sovereign territorial states may legitimately determine 'how many, from where, and in what status' migrants enter the country based on the pursuit of national goals and interests. ${ }^{86}$

The claim of equality of national states in international law underwrites the migration management approach. Central to national state equality are the principles of sovereign authority and territorial integrity, which, within the modern international system, intersect to define the parameters of the nation state. The more or less fixed territorial scope of sovereign authority is enforced under the guise of representing the aspirations of a given polity or citizenry. Here national security equates to the maintenance of internal order and protecting citizens' aspirations from external aggression. This equation allows for the grouping of sovereignty, territoriality and national citizenship. While 'managed migration' is presented as a logical, politically neutral assertion of sovereignty, territoriality and citizenship - one grounded in human rights principles such as the preservation of human dignity - critical scholars have exposed the fallacy of the equation. Scholars have shown how 'security' in fact performs a crucial function in the justification of neoliberal policies deployed to mediate the disruptive 'threat' posed by migration to

81. For an extended engagement with securitization theory see I Boas, Climate Migration and Security: Securitisation as a Strategy in Climate Change Politics (Routledge, New York and Abingdon 2015).

82. See eg, Gregory White, Climate Change and Migration: Security and Borders in a Warming World (Oxford University, New York 2011); Boas, ibid.

83. Bettini (n 72), abstract.

84. Ibid.

85. For an interrogation see AA Smith, 'Migration, Development and Security within Racialised Global Capitalism: Refusing the Balance Game' (2016) 37(11) Third World Quarterly 2119.

86. P Martin, 'International Labour Migration: The Numbers-Rights Dilemma' in R Koslowski (ed), Global Mobility Regimes (Palgrave Macmillan, New York 2011), 204-5. 
the interests of states and capital in the global North. ${ }^{87}$ However, the insight has not been fully extended to climate migration.

\subsection{Planned relocation}

Within neoliberal migration management, climate migration is conceived as a strategy of 'adaptation' and a way of building 'climate resilience'. ${ }^{88}$ A key plank of this policy platform in the international climate regime, found in the Cancun Adaptation Framework, is one of 'planned relocation'. ${ }^{89}$ According to McAdam and Ferris, planned relocation is an adaptive strategy in relation to climate change, generally referring to the 'physical process of moving people'; the movements can be 'voluntary or forced, large-scale or small-scale', and are intended to be permanent. ${ }^{90}$ Planned relocation is often conceived of as a 'climate stress' or 'risk management' strategy that facilitates the voluntary displacement of people into more climate-resilient locations. ${ }^{91}$ The relocation decision, as McAdam and Ferris note, is taken in three contexts: 'as a preventative measure within a country to move people out of particularly hazardous areas, and thereby reduce the risk of future displacement'; 'as a durable solution within a country to enable people who have already been displaced to rebuild their lives elsewhere if it is not safe for them to return home'; and, in exceptional circumstances, as 'a durable solution if large parts (or the whole) of the country of origin are rendered unfit for habitation'. ${ }^{92}$

Most planned relocations that have occurred have been prompted by large development projects in the global South, and have transpired largely according to the dictates of the multilateral development banks. These typically have been accompanied by a process of 'resettlement', which is organized to 'assist relocated persons to replace their housing, assets, livelihoods, land, access to resources and services; to maintain their communities; and to enhance, or at least restore, their living standards' ${ }^{93}$

Planned relocation as a policy solution is said to invoke consideration of human rights and human dignity. When community members are 'well-informed, able to participate in all stages of the decision-making process, given adequate compensation (in the form of assets, incomes and economic opportunities), and have a sense of control over the choice of destination and the process of movement', ${ }^{94}$ they are understandably regarded as being afforded more 'dignity' than when their struggles are simply ignored to the point of disaster. The word 'planned' precedes 'relocation' as a way of

87. Smith (n 85); R Felli, 'Managing Climate Insecurity by Ensuring Continuous Capital Accumulation: "Climate Refugees" and "Climate Migrants", (2013) 18(3) New Political Economy 337.

88. It is important to recognize here that, as Felli argues, "the promotion of "climate migration" as a strategy of adaptation to climate change is located within the tendencies of neoliberalism and the reconfiguration of southern states' sovereignty through governance', R Felli, 'Managing Climate Insecurity by Ensuring Continuous Capital Accumulation: "Climate Refugees" and "Climate Migrants", (2013) 18(3) New Political Economy 337, abstract.

89. UNFCCC, Framework Convention on Climate Change, 15 March 2011, at paragraph 14(f), online: <http://unfccc.int/adaptation/items/5852.php>.

90. McAdam and Ferris (n 11), 140.

91. Lyster (n 75), 431.

92. McAdam and Ferris (n 11), 137, 139.

93. Ibid 141.

94. Ibid 144. 
emphasizing 'the importance of preparation, with the objective that those who move will be resettled and have their livelihoods and incomes restored' ${ }^{95}$ Further explanation is found elsewhere including in the Nansen Principles, developed in 2011, which serve as guidelines for the prevention and management of displacement and the protection of displaced people facing climate change. The Principles call for the development of state-specific resettlement policies. Further, Principle X recommends that '... The voices of the displaced or those threatened with displacement, loss of home or livelihood must be heard and taken into account, without neglecting those who may choose to remain'. ${ }^{96}$

In this section we have outlined the motivations behind the international legal order addressing climate migration. Largely construed as a security threat to the global North, climate migration and the environmental or climate refugee are framed in terms of security and risk. This highly problematic framing invites the response of managed climate migration and the policy prescription of planned relocation organized around a concern for human rights and dignity. What we have learned is that a central aim of climate migration management is to engage in 'proactive, pre-disaster' advance planning so as to prevent large-scale, urgent displacements and 'disorderly' (read: undocumented) migration construed as dangerous.

\section{THE ABSTRACT SUBJECTIVITY OF THE CLIMATE MIGRANT}

In this section we return to the Site $\mathrm{C}$ project and further consider the dominant policy prescription offered by the international legal order - planned relocation. Here, in evaluating a renewable energy project in the global North that will displace and dispossess Indigenous peoples, even one styled as 'climate mitigation', it becomes obvious that planned relocation is a response devoid of meaningful consideration of ongoing, embodied practices of living on the land. The framework deploys abstract and universalist conceptions of land, labour and livelihoods that deny the possibility of people's meaningful relations with specific places. For all of its emphasis on human rights and dignity, planned relocation obscures the actual 'loss and damage' that transpires when real, material and ecological relations that ground people's connections with the land are severed.

'Planned relocation' not only has been advanced as a solution for people fleeing the effects of climate change, but it also has been floated as possibly 'necessary' to implement climate mitigation policies. 'Ironically', as Jane McAdam and Elizabeth Ferris point out, 'the implementation of measures to mitigate the impacts of climate change may also increase the need for planned relocation. Most obviously, the construction of a hydroelectric plant intended to reduce reliance on fossil fuels may mean that communities need to be moved'. ${ }^{97}$

The Site C dam, as a climate mitigation measure akin to the type McAdam and Ferris describe, could then conceivably be one that would be a justified candidate for 'planned relocation' in the logic of this legal order. Our intention in undertaking this analysis is two-fold: it is both to suggest that those displaced and dispossessed by the green energy economy should be considered 'climate change refugees' caught

95. McAdam and Ferris (n 11), 143.

96. For a discussion of the Nansen Principles see 'The Nansen Conference: Climate Change and Displacement in the 21st Century' (June 2011), online: <http://www.unhcr.org/4ea969729. pdf>.

97. McAdam and Ferris (n 11), 142. 
within 'sacrifice zones' of global capitalism, and to demonstrate that the framework constructed by the international legal order to 'address' this kind of injustice produces policy prescriptions that border on the absurd.

By interrogating planned relocation as a key strategy within climate migration management - applying its policy prescriptions in the context of the Site C dam we gain perspective on the production of subjectivities in relation to climate migrants in the dominant international legal order. We advance two central ways in which the climate migration management approach constructs the abstract subject of the climate migrant: it discounts the possibilities of meaningful connections to specific places, and it obscures the actual 'loss and damage' that transpires when people have to relinquish embodied practices of living on the land.

\subsection{Connections to places}

The climate migration management approach tends to treat places as if they are generally interchangeable. As an example, when speaking of whether relocated communities are satisfied with the move, whether they judge their movement to have been voluntary or not, and their overall well-being post-relocation, McAdam and Ferris explain that a key consideration is 'the availability of livelihoods in the destination' ${ }^{98}$ The implication is not only that any place is as good as any other, as long as all the amenities are provided, but also that any livelihood will do. It completely discounts the possibility that people will suffer a loss in relation to their inability to be on the land, or to undertake a specific livelihood in a specific place. ${ }^{99}$

Statements made by the Indigenous people of the Peace Valley invoke the characteristics of unique places with spiritual and cultural significance for them: places of 'deep connection' to their pasts and futures. People who gave testimony to the JRP explained how fishing was a traditional practice that depended on specific places, species and means. They emphasized how these specific fishing spots were crucial to the community's cultural and subsistence activities. The traditional practices of gathering berries and sacred medicines, and holding ceremonies, of visiting ancestral burial grounds, are practices specific to place. Further, the river valley itself holds a specific historical significance. Yvonne Tupper, one of the Treaty 8 First Nation Stewards of the Land, participated in the protest camp at the historic Rocky Mountain Fort, close to where the Moberly River meets the Peace River, up-river from the proposed Site C dam site, for several months in 2016. She states:

Historically and still today, the Peace River has been the entranceway to vast bountiful lands and waters, as well as being the foothold that has welcomed and provided for many different

98. Ibid 145.

99. It is perhaps unfair to equate the kinds of considerations that are appropriate for people fleeing the effects of climate change (for whom there are perhaps no 'places' to go back to, or for whom their livelihoods have already been lost to the ravages of extreme weather or rising sea levels) with the kinds of considerations that would be relevant for people facing pressure to relocate in order to accommodate a renewable energy project, even one with a climate change mitigation purpose. But, as these kinds of relocations are contemplated in the literature, and they are predicted to become more and more common as humanity comes face to face with the dire atmospheric and geological truths of the Anthropocene, and since the Site C dam is real and going ahead, despite the 'displacement' and dispossession of Indigenous peoples from their traditional territories, we consider ours to be a useful intervention. 
groups of people and enterprises ... [in] peaceful relationships with First Nations: explorers were guided into new places; fur traders were taught ways to survive and prospered; gold seekers passed through freely; and, pioneer families established farming homesteads.

There are two significant events that explain why we are united and with peaceful intent to protect and care for the Peace River Valley. First, along these waters and islands of the Peace River, battling Beaver (also known as the Dane-zaa) and Cree agreed to a truce so that their future generations could co-exist and be sustained by the land and water in perpetuity. Secondly, the signing of the Treaty in the Peace River Valley between First Nations and the Crown promised that we would live a peaceful shared co-existence. Also, First Nations were guaranteed to be able to always pursue their usual vocations prior to entering into Treaty and without forced interference. ${ }^{100}$

Doig councillor Kelvin Davis explained his opposition to Site C during a tour of traditional sites along the Peace River, stating: 'The land is more valuable to us the way it is. For this to be under water is unthinkable'. ${ }^{101}$

\subsection{Embodied practices on the land}

People experience the world through their bodies; as Nishnaabeg scholar Leanne Betasamosake Simpson states, it is a process of "coming to know [in] the pursuit of whole body intelligence'. ${ }^{102}$ This process 'takes place in the context of family, community and relations' and is 'realized collectively'. ${ }^{103}$ It 'comes through the land'. ${ }^{104}$ The climate migration management approach is devoid of meaningful consideration of these ongoing, embodied practices of living on the land. The approach tends to abstract labouring bodies from consideration. In particular, although 'livelihoods' are recognized as important in the processes of planned relocation, they are treated as distinct and separable from land. As an example, the guiding objective behind 'Involuntary Resettlement' offered by the World Bank is 'to assist displaced persons in improving or at least restoring their livelihoods and standards of living in real terms relative to pre-displacement levels ...' ${ }^{105}$ This betrays a notion that livelihoods are reducible to incomes; they exist independently of land. The objective operates as if embodied practices of living on the land can be replaced; as if ways of earning a living are not connected to ways of being. It reveals an abstract and disembodied conception of labour.

The central livelihoods at stake in the Site C project include fishing, hunting and trapping. Marten, fisher, beaver and lynx are among the common animals trapped in

100. Treaty 8 Stewards of the Land, online: <http://www.newswire.ca/news-releases/treaty-8stewards-of-the-land-set-out-conditions-to-protect-lands-565628881.html>.

101. L Pynn, 'First Nations Split over BC Hydro's Site C Dam Megaproject' Vancouver Sun (12 December 2013).

102. LB Simpson, 'Land as Pedagogy: Nishnaabeg Intelligence and Rebellious Transformation' (2014) 3(3) Decolonization: Indigeneity, Education \& Society 1,7.

103. Ibid.

104. Ibid. Simpson is speaking about the Nishnaabeg culture and epistemology specifically; many Indigenous peoples across Canada and elsewhere, however, express similar ideas in relation to embodied practices of living on the land. See also J Borrows, 'Living Between Water and Rocks: First Nations, Environmental Planning and Democracy' (1997) 47(4) UTLJ 417, describing how complex systems for governing people-place relationships were (and are) systematically undermined through ongoing settler-colonial violence in Canada.

105. World Bank, Operations Manual, Operational Policies, OP-4.00, Table A1 (July 2005), 5. 
the valley. Members of the Saulteau First Nations presented evidence to the JRP that 'traplines have been used for family income for several generations and are also used for transmission of cultural practices' ${ }^{106}$ Fishing, as mentioned, is a traditional and contemporary practice that depends on specific places, species and means. Moberly River Arctic grayling, mountain whitefish and Halfway River bull trout are fish species that are expected to be possibly 'wiped out' by the dam, while species such as lake trout and the introduced Kokanee are expected to flourish. ${ }^{107}$ The Site C proponent, BC Hydro, claims that the transformation of the Peace River ecosystem from a river to a reservoir will 'create a new and productive aquatic ecosystem' that will 'support a community of equal or greater productivity than the existing riverine environment'. ${ }^{108}$ The JRP disagreed, concluding that the dam will produce a 'net loss of fish habitat' and cause a 'profound change in the type and character of the remaining habitat'. ${ }^{109}$

These contortions fit comfortably with the migration management approach, which makes essentially the same move. That is, to assign quantitative value to abstract categories such as 'livelihoods' and 'aquatic ecosystems', without paying attention to the specificities of interactions; without understanding that bodies, land and livelihoods are interconnected in ways that are profoundly significant. As Grand Chief Phillip explains, 'The proposed Site C project will irreparably harm and adversely impact the environment and the Treaty 8 First Nations and all residents whose lives are entwined with the health of the land and waters'. ${ }^{110}$

It is clear that in confronting these impacts as expressed by those who will experience them, proponents of contemporary managed migration - armed with sterile prescriptions for 'planned relocations' - deny and suppress 'the full significance of embodied, socially and materially situated life'. ${ }^{111}$ Instead of the 'autonomous abstract human of traditional international human rights universalism' that Anna Grear exposes in other contexts, the legal subject of the 'climate migrant' must be seen, however, as 'a living flesh and blood being' embedded in the 'potentialities and limitations of a fully embodied, particular and collective life - life fully open to the draughts, predations and complexities, moreover, of a distinctly uneven

106. JRP Report (n 8), 20.

107. L Pynn, 'Fish Species and Local Climate to be Altered by Site C Dam's Reservoir: Joint Review Panel' The Vancouver Sun (5 September 2014), online: <http://www.vancouversun. $\mathrm{com} /$ Fish+species+local+climate+altered+Site+reservoir+Joint+Review+Panel/9824876/story. html>. See also M Hume, 'Proposed Fish Ladder at Site C Dam Called "Bizarre," but is Quite Common' The Globe and Mail (10 April 2016), online: <http://www.theglobeandmail.com/ news/british-columbia/proposed-fish-ladder-at-site-c-dam-called-bizarre-but-is-quite-common/ article29582193/>.

108. S Cox, 'BC Hydro's Bizarre, Multi-Million Dollar Boondoggle to Save Fish from Site C Dam' (4 April 2016) DeSmog Canada, online: <http://www.desmog.ca/2016/04/04/bchydro-s-bizarre-multi-million-dollar-boondoggle-save-fish-site-c-dam>.

109. Ibid.

110. J Dillon, 'British Columbia Must Respect Indigenous Peoples' Right to Free, Prior and Informed Consent Before Proceeding with Site C Dam' (18 January 2016) KAIROS, online: $<$ http://www.kairoscanada.org/site-c-dam>.

111. A Grear, 'The Closures of Legal Subjectivity: Why Examining "Law's Person" is Critical to an Understanding of Injustice in an Age of Climate Crisis' in A Grear and L Kotzé (eds), Research Handbook on Human Rights and the Environment (Edward Elgar, Cheltenham, UK 2015) 90 [Grear]. 
globalized world'. ${ }^{112}$ In the Site C example, we can see how these materialities are (and must be within the ideological imperatives of the neoliberal system) 'relentlessly pressed from law's view' ${ }^{113}$ such that the managed migration approach can uphold its purported concurrency with principles of human rights and human dignity. But, instead of continually pressing such living materialities back, we argue that we should give them, in Grear's words, a 'renewed normative significance'.114

\section{CONCLUSION}

Our aim here has been to make visible the connections that the contemporary managed migration approach erases: those that run through and across bodies, through ecosystems and between generations. We insist that people are social beings embedded in ecological contexts, material contexts, with bio-physical elements as critical actors in unfolding histories. As Leanne Betasamosake Simpson states, 'being tied to land also means being tied to an unwritten, unseen history of resistance'. ${ }^{115}$ With this in mind, and in the Canadian context, it is impossible to ignore the synergies between the effect of the climate migration management approach's prescription for planned relocation and the imperatives of ongoing processes of settler colonialism. Planned relocation in the climate context - especially in the context of climate-mitigation-driven displacements - has the effect of converting landlabour to 'higher' and more productive uses, understood in Lockean terms. ${ }^{116}$ In fact, in repositioning relocation and resettlement within a longer history, McAdam contends that a 'core premise' was that if 'populations could be transferred from high-density "danger zones" to low-density areas, then land could be used more efficiently ...' ${ }^{117}$ This makes climate mitigation a new plank of the settler-colonial capitalist platform in Canada. The severing of land-labour-livelihood connections that will flow from the Site $\mathrm{C}$ dam is a clear instantiation of how the settlercolonial imperative of erasing Indigenous presence on the land presses on in the contemporary moment. ${ }^{118}$

Further, we have demonstrated that the dominant international legal order on climate migration management, specifically the prescription of planned relocation, undermines the lived experience of affected people. Planned relocation is devoid of meaningful consideration of ongoing, embodied practices of living on the land, and, as such, in the context of the global North, serves to further entrench patterns of climate injustice. Planned relocation deploys abstract and universalist conceptions

112. Ibid 98 (drawing on R Radhakrishnan, Theory in an Uneven World (Blackwell, Oxford 2003)).

113. Ibid.

114. Ibid.

115. Simpson (n 102), 20.

116. For a trenchant interrogation of Lockean (and wider Western political) conceptions of private property and productive use see E Wood, Liberty and Property: A Social History of Western Political Thought from Renaissance to Enlightenment (Verso, London \& New York 2012).

117. J McAdam, 'Relocation and Resettlement from Colonisation to Climate Change: The Perennial Solution to "Danger Zones"” (2015) London Review of International Law 93, 94-5. 118. For discussion, see AA Smith, 'A Political Economy of Sociolegality in Settler Colonial Canada', in M Thomas, L Vosko and C Fanelli (eds), Change and Continuity: Rethinking the New Canadian Political Economy (McGill-Queen's, forthcoming). 
of land, labour and livelihoods that deny the possibility of people's meaningful relations with specific places.

This state of affairs does not bode well for the future of the so-called green energy economy. It gives rise to the reasonable expectation that a policy emphasis on renewable energy development as climate 'mitigation' will continue to produce burdens on marginalized communities - will distribute benefits and burdens along the same familiar axes as climate change itself - because the underlying structural relations of power remain unchanged. This should not come as a surprise for, as Turner argues, 'the very design of the law itself is fundamentally predisposed to environmental degradation and forms part of a dysfunctional global legal architecture which cannot achieve environmental sustainability'. ${ }^{119}$ What we have demonstrated in this article is that the dominant international legal order, even when it embraces and engages with the principles of human rights and human dignity, produces solutions that continue to protect and advance the interests of settler-colonial capitalism. 'It is the poorest people and nations of the earth, and the most socio-economically vulnerable members of societies - including in the [g]lobal North - who face the fall out of long-standing exploitation of "nature" in the name of "progress" - including the social and environmental fall outs now manifesting as climate crisis'; ${ }^{120}$ and, as we demonstrate, now also manifesting as 'legitimate' policy reactions to the climate crisis.

119. SJ Turner, A Global Environmental Right (Routledge, London 2013) 32.

120. Grear (n 111), 94. 